\title{
Effect of Using Thyme, Carrot and Hibiscus to Some Crackers Products on their Nutritional and the Rapeutical Value \\ Lobna A. Shelbaya
}

Home Economics Dept., Faculty of Specific Education, Mansoura university, Mansoura, Egypt.

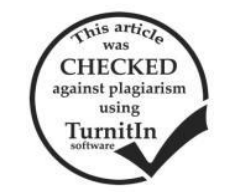

\section{ABESTRACT}

The main objective of the present study was carried to evaluate the possibility of enhancing antioxidant activities by using $10 \%$ of thyme, carrot and hibiscus powder fortified to crackers as natural colored antioxidants to produce healthy crackers, chemical composition and rheological properties were carried out, determination of phenolic compounds and antioxidant activity\% noticed that thyme powder had the highest level of total phenols $(12366 \mathrm{mg} / 100 \mathrm{~g})$, followed by carrot powder which was (5087.4 $\mathrm{mg} / 100 \mathrm{gm})$ and hibiscus had $(4262.9 \mathrm{mg} / 100 \mathrm{~g})$, while antioxidant activity were $96.7 \%$ for thyme, $89.59 \%$ for carrot and $86.17 \%$ for hibiscus. Also, this work aimed to study the anti-hyperlipidemic activities of crackers with $100 \%$ wheat flour and crackers fortified with natural additives (thyme, carrot and hibiscus powder) on rats. The experiment was performed in 36 male rats distributed into 6 equal groups. Group (1) was kept as a normal control (fed on a basal diet), while rats of the other five groups were fed on hypercholesterolemic diet for 8 weeks to induce hypercholesterolemia. Rats of group (2) were left as a positive control and those of groups $(3,4,5$ and 6) were given unfortified cracker $100 \%$ wheat flour (CWF), 10\% thyme(Cth), 10\% carrot (CCa ) and 10\% hibiscus (Chi). The results revealed that rats consumed crackers fortified with natural additives decreases adiposity index, body mass index, Serum Cholesterol, Triglycerides (TG), Low density lipoprotein cholesterol (LDL-C) and Very low density lipoprotein cholesterol (VLDL-C), while there was an increase in serum HDL-C. Also showed decreases in serum ALT, AST, AP, Uric acid, Urea and Creatinine levels. The best results showed in thyme crackers then carrot followed by hibiscus for the treatment of hypercholesterolemic.

Keywords: Natural Additives, Crackers, Total phenols, Hyperlipidemia, Rats

\section{INTRODUCTION}

Crackers are baked food typically made from flour, flavorings such as salt, seeds, herbs and/or cheese, may be added sprinkled on top or in dough before baking Sompong, et al., (2011). Some of these crackers contain elements, vitamins that are beneficial for health (Wangcharoen et al. 2005). However, may be crackers are harmful to health, because they have high content of oil, fat, sugar or salt which can cause dental caries, malnutrition, obesity, diabetes, coronary heart disease and may increased serum total cholesterol. (Sutharut and Sudarat, 2012).

Crackers using for its micronutrients, crackers regard as snake than a meal and therefore unlikely to replace meals given to child home and also it is easy to disrupts, no preparation, long shelf life (Asal, 2004 ).

Some modern plants consumed as a natural spices and herbs, containing good amounts of several nutrients, nutritional sources of minerals, vitamins, carotenoids and phenols ( Guil et al ., 1997).

There is a worldwide to return to natural economic resources, such as thyme (Thymus vulgaris L.) which is widely cultivated as tea, spice and herbal medicine (Domaracky et al., 2007). The leaves of thyme and its essential oil have been used in foods for flavour, aroma and preservation so added to meat, fish and food products.

Thyme uses changed to a serious drug in rational phytotherapy after a traditional herb. Thyme has various beneficial effects, as antiseptic, antimicrobial, bactericidal, anthelmintic, antioxidant properties and it has recently suggested as a natural antioxidant (Rasooli et al., 2006). Thyme is an excellent source of iron, manganese and vitamin K. It is also a very good source of calcium (Sasaki et al., 2005). Moreover, thyme, promotes blood circulation and functions as an exciting stimulant for the entire system.

The therapeutic effect of thyme inasmuch of its contents of flavonoids, thymol, eugenol, carvacrol, aliphatic phenols as well as saponins, tetramethoxylated flavones and luteolin. (Dorman and Deans,2000 and Amarowicz et al., 2008).

Vegetables and fruits are valuable sources of health promoting substances active in neutralization of reactive oxygen species. Among them carrot (Daucuscarota L.) has nutritional value and high concentration of bioactive constituents (Maria et al., 2013). Carrot is one of the most important nutritious vegetables. It is the richest source of vitamin A and $\beta$-carotene. (Deng et al., 2012).

Carotenoids are precursors of vitamin A as well as excellent antioxidants which has been commonly known (Simon 1990). Consumption of carrot and its products has increased due to the recognition of antioxidant and anticancer activities of $\beta$-carotene in carrot, (Dreosti, 1993).

Hibiscus sabdariffa L., also known as roselle, it used as food and fibre. In China seeds hibiscus used for oil and plant is used as medicinal properties. Additionally, it is used in the food industries and pharmaceutical. Hibiscus has phytochemical, pharmacological and toxicological properties (Ali and Blunden, 2005) and it has an effectiveness in treatment of hypertension and hyperlipidemia effect (Hopkins, et al. 2013).

The Hibiscus leaves are good source of polyphenolic compounds. Neochlorogenic acid, chlorogenic acid, cryptochlorogenic acid, caffeoylshikimic acid are major identified compounds and flavonoid compounds such as quercetin, kaempferol and their derivatives. (Zhen and Jing 2016). Flowers are rich in anthocyanins, as well as protocatechuic acid. Dried flower contain flavonoids as gossypetin, hibiscetine and sabdaretine. Major pigment hibiscin which has been identified as daphniphylline. Roselle seeds are a good source of antioxidants, particularly gamma-tocopherol. (Mohamed et al. 2007 ).

The present study was carried to evaluate the possibility of enhancing antioxidant activities by using thyme, carrot and hibiscus powder added to crackers as natural antioxidants to help in industry to attract children to natural colours and its nutrition and therapeutic effect.

\section{MATERIALS AND METHODS}

\section{Materials:}

Thyme (Thymus vulgaris L.), Carrot and Hibiscus sabdariffa $L$. were purchased from local market for herbs and medicinal plants, Cairo, Egypt. 
Soft wheat flour $72 \%$ extraction was obtained from local market in Cairo, soy flour and soy milk were obtained from soy factory.

Biochemical and durg:

Cholesterol: were obtained from El-Gomhoria Pharmaceutical Company, Cairo, Egypt.

Kits: Biochemical kits were obtained from Gama Trade Company, Dokki, Egypt.

Animals: A total of 36 male Sprague-Dawley rats $(100 \pm 10$ g) were provided from of National Research Center, Cairo, Egypt. Rats were housed as groups in wire cages under the normal laboratory conditions. The basal diet prepared according to (NRC 1995). The vitamin and mineral mixture had the prepared according to (Campbell, 1963).

Methods :

\section{-Cracker preparation:}

The unfortified cracker was prepared using $100 \%$ wheat flour $\left(\mathrm{C}_{\mathrm{WF}}\right)$, other formulated using amounts of powder $10 \%$ thyme powder $\left(\mathrm{C}_{\mathrm{th}}\right)$ to produce green dough, $10 \%$ carrot powder $\left(\mathrm{C}_{\mathrm{Ca}}\right)$ to produce yellow dough and $10 \%$ hibiscus powder $\left(\mathrm{C}_{\mathrm{hi}}\right)$ to produce red dough with 25 $\mathrm{ml}$ soy milk, $20 \mathrm{gm}$ butter, $25 \mathrm{gm}$ sugar, $2 \mathrm{gm}$ salt, $3 \mathrm{gm}$ baking powder, $3 \mathrm{ml}$ vanilla flavor. Blend the ingredients, bake in an oven to $190 \mathrm{c}$ according to the method of (Abd El Rahim et al.2003).

Organoleptic evaluation of crackers:

Crackers samples were evaluated organoleptically by a panel of ten panelists for appearance, color, thickness, crispiness, shrinkage, taste and odor as the method described by Smith (1972).

Chemical analysis:

-Analytical Methods: Moisture content, protein, crude fat and ash were determined in unfortified and fortified crackers according to (A.O.A.C.1995). Total carbohydrates were calculated by difference.

Determination of antioxidant activity\%: Antioxidant activity $\%$ in thyme, carrots and hibiscus powder were determined according to (A.O.A.C. 2007) at Central Lab. of Food Technolpgy Research Institute Agric. Rec. Cent., Egypt.

Determination of phenolic compounds: Phenolic compounds were determined by HPLC as gallic in thyme, carrots and hibiscus powder according to the method of (Goupy et al., 1999), in Food Technolpgy Research Institute Agric. Rec. Cent., Egypt.

\section{-Rheological properties of dough:}

\section{1- Farinograph parameters:}

Water absorption and other mixing characteristics of dough prepared from control and all treatment samples were determined according to the methods described by (A.A.C.C., 2002) by using farinograph instrument (300g. of flour for each samples), at Food Technology Research Institute at Giza city, Egypt.

\section{2- Extensograph parameters:}

The Extensograph parameters is dough resistance to extension (R) (B.U(Bran bender unit), dough extensibility $(\mathrm{E})(\mathrm{mm})$, proportional number (P.N)(R\E) and dough energy $\left(\mathrm{cm}^{2}\right)$ for wheat flour and all treatment samples were measured according to procedures described in the (A.A.C.C., 2002) by using Extensograph instrument (300g. of flour for each samples), at Food Technology Research Institute at Giza city, Egypt.

Induction of obesity:

Hypercholesterolemic prepared by adding $10 \%$ lard, $1 \%$ cholesterol and $5 \%$ bile salt to the diet fed for 8 weeks induce a case of hypercholesterolemia as described by (Knapka and Judge 1974).

\section{Experimental design:}

Thirty six adult male albino rats Sprague Dawley strain $(100 \pm 10 \mathrm{gm})$ obtained from the Experimental Animal House of Helwan, Egypt. All rats were allowed to free access drinking of water and basal diet for seven days adjustment to the laboratory environment. Then rats were randomly divided into 6 groups (each of 6 rats) as following:

Group (1): Negative control (ve-); rats fed on basal diet.

Group(2):Positive control (ve+); rats fed on hypercholesterolemic diet.

Groups (3): Rats fed on hypercholesterolemic diet with crackers control $100 \%$ wheat flour $\mathrm{C}_{\mathrm{WF}}(10 \mathrm{~g} / 100 \mathrm{~g} / \mathrm{diet})$.

Group (4): Rats fed on hypercholesterolemic diet with fortified crackers with $10 \%$ thyme powder $C_{t h}(10 \mathrm{~g} / 100 \mathrm{~g}$ diet $)$.

Group (5): Rats fed on hypercholesterolemic diet with fortified crackers with $10 \%$ carrot powder $\mathrm{C}_{\mathrm{Ca}}(10 \mathrm{~g} / 100 \mathrm{~g}$ diet $)$. Group (6): Rats fed on hypercholesterolemic diet with fortified crackers with $10 \%$ hibiscus powder, $\mathrm{C}_{\mathrm{hi}}(10 \mathrm{~g} / 100 \mathrm{~g}$ diet $)$.

After eight weeks experiment, body weight of rats was recorded, and rats were then euthanized by prolonged exposure to ether anesthetic. The abdomen was opened, and body fats, including mesenteric, visceral, epididymal and retroperitoneal fats were carefully dissected out and total fat mass was weighed. The adiposity index (Ad. I) was calculated by dividing total body fat mass by body weight and multiplied by $100($ Ad. $\mathrm{I}=$ fat weight $[\mathrm{F} . w \mathrm{t}] /$ Final B.wt $\times 100)$ as described by (Pichon et al., 2006).

Rats were weighed in grams and lengths were measured in $\mathrm{cm}$ at the end of eight weeks study. The body mass index (BMI) was calculated (by dividing the body weight in kilograms by the length in meters squared) (Buettner et al., 2006). The body weight and body length were measured and used to determine the following parameters:

Body Mass Index $($ BMI $)=$ body weight $(\mathrm{g}) /$ length $^{2}(\mathrm{~cm})$

At the end of the experiment period, the rats were fasted overnight then the rats were anaesthetized and sacrificed and blood samples were collected from the aorta. The blood samples were centrifuged and the serum was carefully separated into dry clean Wassermann tubes by using a Pasteur pipette and kept frozen till analysis at $-20^{\circ} \mathrm{C}$.

Biochemical analysis of serum:

Determination of lipids paeameters were determined by enzymatic methods as follows: Total cholesterol (TC), high-density lipoprotein cholesterol (HDL-c) and triglycerides (TG)), according to (Richmod, 1973, Lopes-Virella,et al., 1977, and Fossati and Prenape, 1982). While (LDL-c and VLDL-c) were calculated according to the equation of (Friedwald et al., 1972). Atherogenic Index (Total cholesterol / HDLcholesterol) were calculated according to the equation of (Golay et al ., 1990).

Uric acid was determined in the serum according to the method described by Fossati et al., (1980). Urea nitrogen was determined according to Patton and Crouch, (1977). Creatinine was determined according to Bartels et al., (1972). Serum alanine and aspartae aminotransferase (ALT, AST), alkaline phosphates (AP) enzymes, were estimated according to Reitman 
and Frankel (1957), Kind and King (1954) and Weichselbaum (1946) respectively.

\section{Determination of serum antioxidant parameters}

Total Antioxidants Capacity (TAC), Superoxide Dismutase (SOD) activity, and Malondialdehyde (MDA) were determined according to Nishikimi et al., (1972); Cao et al., (1993) and Ohkawa et al.,(1979), respectively. While Acetylcholine esterase (AChE) activity was determined colorimetrically according to Hestrin (1949).

Statistical analysis:

The obtained data were statistically analyzed using computerized SPSS (Statistic Program Sigmastat, Statistical Soft-Ware, SAS Institute, Cary, NC). Effects of different treatments were analyzed by one way ANOVA (Analysis of variance) test using Duncan's multiple range test and $\mathrm{p}<0.05$ was used to indicate significance between different groups (Snedecor and Cochran, 1967).

\section{RESULTS AND DISCUSSION}

The organoleptic properties of crackers made from wheat flour and fortified crackers with thyme, carrot and hibiscus powder:

Crackers supplemented by $10 \%$ thyme, carrot and hibiscus powder were sensory evaluated with different parameters appearance, color, thickness, crispness, shrinkage, taste, odor and overall acceptability values and compared with crackers from wheat flour as presented in Table (1). Formula contained 10\% thyme, carrot and hibiscus powder showed acceptability with ability value $90.4,92.9$ and $93.2 \%$ respectively. Abdel Azim (2007) reported that natural plants have been widely used in many food products as crackers, biscuits and cookies which has great economic importance and often stored for extended periods before consumption.

Table 1. The organoleptic properties of unfortified crackers made from wheat flour and fortified crackers with thyme, carrot and hibiscus powder.

\begin{tabular}{|c|c|c|c|c|c|c|c|c|}
\hline Samples of biscuits & $\begin{array}{c}\text { Appearance } \\
(10)\end{array}$ & $\begin{array}{c}\text { Color } \\
(15)\end{array}$ & $\begin{array}{c}\text { Thickness } \\
\text { (15) }\end{array}$ & $\begin{array}{c}\text { Crispness } \\
\text { (15) }\end{array}$ & $\begin{array}{c}\text { Shrinkage } \\
\text { (15) }\end{array}$ & $\begin{array}{c}\text { Taste } \\
\text { (15) }\end{array}$ & $\begin{array}{c}\text { Odor } \\
\text { (15) }\end{array}$ & $\begin{array}{l}\text { Total } \\
(\mathbf{1 0 0}) \\
\end{array}$ \\
\hline unfortified & 9 & 14 & 13 & 14 & 14 & 14 & 14.5 & 92.5 \\
\hline Fortified crackers with $10 \%$ Thyme & 9 & 13 & 13 & 14 & 14 & 13.5 & 13.9 & 90.4 \\
\hline Fortified crackers with10\% Carrot & 9 & 14 & 13 & 14 & 14 & 14.7 & 14.2 & 92.9 \\
\hline Fortified crackers with $10 \%$ Hibiscus & 9 & 14 & 13 & 14 & 14 & 14.7 & 14.5 & 93.2 \\
\hline
\end{tabular}

W.F = Wheat flour

Chemical composition of crackers made from wheat flour CWF and fortified crackers with thyme, carrot and hibiscus powder:

Data in Table (2) showed the gross chemical composition of crackers processed from wheat flour $72 \%$ and thyme, carrot and hibiscus powder. Results indicated that moisture content was $8.0 \%$ in crackers formulae control. All crackers formulae were higher in moisture content. Results also, indicated that protein content of control formula was higher than those of the other mixtures. This could be due to that the ratio of additives namely thyme, carrot and hibiscus powder contained low amount of protein in comparing with wheat flour. The ash content in crackers formula with thyme, carrot and hibiscus powder was increased slightly comparing with crackers with wheat flour only. These results are in agreement with those given by (Abd El Rahim et al.2003) Who indicated that crackers was higher score in fiber due to high content of its additives.

Table 2. Chemical composition of crackers unfortified and fortified with thyme, carrot and hibiscus powder.

\begin{tabular}{lccccc}
\hline Samples of crackers & Moisture & Crude protein & Crude fat & $\begin{array}{c}\text { Ash } \\
\text { \% }\end{array}$ & $\begin{array}{c}\text { Carb. } \\
\text { \% }\end{array}$ \\
\hline unfortified & 8.00 & 10.53 & 12.33 & 2.0 & 67.14 \\
Fortified crackers with10\% Thyme & 8.50 & 8.77 & 13.33 & 2.50 & 66.9 \\
Fortified crackers with10\% Carrot & 9.8 & 8.51 & 13.00 & 2.41 & 66.29 \\
Fortified crackers with10\% Hibiscus & 8.70 & 8.0 & 13.4 & 2.9 & 67.0 \\
\hline
\end{tabular}

${ }^{*}$ Carb=carbohydrate

Total phenols and antioxidant activity contents of natural additives used in crackers formulation:

Total phenols and antioxidant activity \% content of thyme, carrot and hibiscus (on dry weight basis) were shown in Table (3). It could be noticed from the results that thyme powder had the highest level of total phenols $(12366 \mathrm{mg} / 100 \mathrm{~g})$, followed by carrot powder which was (5087.4 mg/100gm) and hibiscus has (4262.9 mg/100g) while antioxidant activity were $96.7 \%, 89.59 \%$ and $86.17 \%$ respectively for thyme, carrot and hibiscus. These result of carrot at accordance with (Ally 2001).

Table 3. Total phenolic content $(\mathrm{mg} / \mathbf{1 0 0 g})$ and antioxidant activity (DPPH) radical \% of natural additives used in crackers formulation.

\begin{tabular}{lcc}
\hline Samples & $\begin{array}{c}\text { Total phenolic } \\
\text { Content }(\mathbf{m g} / \mathbf{1 0 0 g})\end{array}$ & $\begin{array}{c}\text { Antioxidant activity } \\
\text { radical (DPPH) } \%\end{array}$ \\
\hline Thyme & 12366.0 & 96.7 \\
Carrot & 5087.4 & 89.59 \\
Hibiscus & 4262.94 & 86.17 \\
\hline
\end{tabular}

Phenolic compounds of natural additives:

Polyphenolic compounds are very important constituents in activating lipid free radical chains and preventing hydroperoxide. Data in Table (4) showed that the main phenolic acids identified in thyme powder was Salicylic acid (177.7), while carrot powder had high contents of Chlorogenic, Catechol 299.72, 108.3 respectively. While hibiscus contained P-oH-Benzoic, benzoic, Epicatechen, Salicylic and Ellagic their values were $1260.7,1200,870.3,625.5$ and 540.01 respectively.

Carrot contains phenolic constituents as chlorogenic acid (Arscott and Tanumihardjo, 2010). Carrots contained mainly hydroxyl cinnamic acid $42.2 \%$, chlorogenic acid represented $61.8 \%$ of total phenolics (Zhang and Hamauzu, 2004). Chlorogenic acid, caffeic acid, $p$ hydroxybenzoic acid, ferulic acid and other cinnamic acid isomers predominated in carrots of different colors (Sun et al., 2009). 
Table 4. Phenolic compounds of natural additives.

\begin{tabular}{lccc}
\hline $\begin{array}{l}\text { Phenolic } \\
\text { compounds }\end{array}$ & Thyme & Carrot & Hibiscus \\
\hline Pyrogallol & 7.7 & ---- & 177.76 \\
4-Amnobenzoic & ----- & ---- & 15.52 \\
Chlorogenic & 13.78 & ---- & 225.68 \\
P-oH-Benzoic & 12.29 & ---- & 1260.70 \\
Epicatechen & 7.06 & ---- & 870.39 \\
Caffeic & 5.99 & 29.35 & 70.30 \\
Vanillic & 2.77 & 17.97 & 69.74 \\
Ferulic & 5.89 & 15.65 & 50.82 \\
Benzoic & ----- & 80.24 & 1200.08 \\
Salicylic & 177.7 & ----- & 625.52 \\
Coumarin & 7.001 & ----- & 160.82 \\
Ellagic & 16.95 & 17.70 & 540.01 \\
Cinnamic & 8.006 & ---- & 26.40 \\
Gallic & 0.52 & 15.77 & ------ \\
Protocatechuic & 13.89 & 6.44 & ------ \\
Syring & ----- & ----- & ----- \\
Catechol & ---- & 108.36 & ------ \\
Caffiene & ----- & 7.71 & ----- \\
Chlorogenic & ----- & 299.72 & ----- \\
\hline
\end{tabular}

Anthocyanins found in hibiscus are delphinidin-3sambubioside, delphinidin-3- glucose cyaniding and 3 sambubioside. (Christian et al. 2006). Hibiscus also contains alkaloids, L- ascorbic acid , citric acid, anisaldehid, $\beta$-carotene, gossypetin, hibiscetin, $\beta$-sitosterol, galactose and mucopolysaccharides (Hirunpanich, et al. 2005).

Free radicals can be destroyed by antioxidants present in the body so that the biological damage by phenolic compounds can be avoided (Vincent et al.2004).

The water extract of dried hibiscus showed the presence of catechin $(4.25 \%)$ and ellagic acid (28.20\%) (Lin et al., 2012), while (Yang et al., 2010) found that hibiscus contained gallocatechin gallate (27.98\%) protocatechuic acid $(24.24 \%)$, caffeic acid (19.85\%), catechin $(2.67 \%)$ and gallocatechin $(2.44 \%)$.

\section{Rheological properties of dough: Farinograph parameters}

The results in Table (5) showed that, the flour control absorbed $60.6 \%$ of water, when the flour with carrot absorbed $69.4 \%$ of water, hibiscus absorbed $63.3 \%$ then thyme absorbed $61.23 \%$, These result indicated to increase in absorption of water when added natural additives because its high content of fiber. These results agreed with (Unver and Domolds 1976) who found that increase in water absorption of dough when protein content decreased. Table (5), showed that, flour control had arrival time 1.5 and flour with natural additives increased in arrival time which ranged from 1.7 to $2.3 \mathrm{~min}$. also Table (5), showed that, dough development in flour control equal $1.0 \mathrm{~min}$, when flour with natural additives had dough development more than flour control which equal $1.5 \mathrm{~min}$. At these study value of dough stability for flour control were $1.0 \mathrm{~min}$ which indicated to weak dough, when value of dough stability for flour with natural additives were 2.0 min. for thyme dough, 3.5 for carrot dough and 1.5 for hibiscus dough. These results indicate to the flour with natural additive powders had the ability barrier to gas which effects on the freshness of the product. Table (5), showed that, the degree of softening of flour control were 70 B.U, when the degree of softening of flour with thyme and hibiscus powder were $80 \mathrm{~B} . \mathrm{U}$, while the degree of softening of flour with carrot powder were 90 B.U these mean that flour with natural additives had the heights degree of softening, these results indicated to the addition powders to flour increase the degree of softening of dough, This result confirms the previous result for dough stability. From these results we can conclude that, the fortified products with thyme, carrot and hibiscus will have lowest staling and lowest firmness than control products, because the high softening led to produce product with antistaling and low firmness. (Dapčević et al. 2009) reported that, degree of softening is predominantly influenced, as it was for the dough stability, by the amount and quality of gluten, these result agree with the result at above.

Table 5. Farinograph parameters of dough formulae from wheat flour and samples with some herbs.

\begin{tabular}{lccccc}
\hline Samples & $\begin{array}{c}\text { Water } \\
\text { absorption }\end{array}$ & $\begin{array}{c}\text { Arrival time } \\
\text { (min) }\end{array}$ & $\begin{array}{c}\text { Dough development } \\
\text { (min) }\end{array}$ & $\begin{array}{c}\text { Dough stability } \\
\text { (min) }\end{array}$ & $\begin{array}{c}\text { Degree of softening } \\
\text { (B.U) }\end{array}$ \\
\hline Unfortified flour & 60.60 & 1.5 & 1.0 & 1.0 & 70 \\
Fortified flour with10\% Thyme & 61.23 & 1.7 & 1.5 & 2.0 & 80 \\
Fortified flour with10\% Carrot & 69.40 & 2.3 & 1.5 & 3.5 & 90 \\
Fortified flour with10\% Hibiscus & 63.3 & 1.9 & 1.5 & 1.5 & 80 \\
\hline
\end{tabular}

Data in Table (6), showed the effect of natural additives on dough elasticity or dough resistance (R), elasticity or resistance of dough from flour control are higher than the elasticity of dough from flour with additives because the elasticity of dough from flour control equal 510 B.U, but the dough from flour with thyme, carrot and hibiscus were 380, 480 and 350 B.U respectively, also Table (6), showed the extensibility of dough control and dough from flour with natural additives, the dough which made from flour with thyme, carrot and hibiscus had a lower value of extensibility than dough control which had $195 \mathrm{~mm}$, Table (6), showed the value of P.N for dough with or without any addition, this result indicated to the flour control had P.N equal 2.6, while thyme and carrot powder dough had 3.6 and 4.5P.N respectively, then the flour with hibiscus had 2.5 P.N. Value of energy for dough which made from flour control was $85 \mathrm{~cm}^{2}$, then the value of flour with carrot powder had higher value was $128 \mathrm{~cm}^{2}$. These results agreed with (Gurpreet et al. 2014) who found that Water absorption increased for all spices and herbs; cinnamon, clove and thyme except for garlic powder. Dough development time was increased by adding cinnamon, clove, garlic and thyme. Incorporation of cinnamon, thyme and clove increased the paste temperature due to high fibre content, so gluten was competing with fibre present in spices and herbs for water.

Table 6. Extensograph parameters of dough formulae from wheat flour and samples with some herbs.

\begin{tabular}{lcccc}
\hline Samples & Extensibility $(\mathbf{m m})$ & Elasticity (B.U) & proportional number (P.N) & Energy (cm2) \\
\hline Unfortified flour & 195 & 510 & 2.6 & 85 \\
Fortified flour with10\% Thyme & 105 & 380 & 3.6 & 67 \\
Fortified flour with10\% Carrot & 105 & 480 & 4.5 & 128 \\
Fortified flour with10\% Hibiscus & 140 & 350 & 2.5 & 80 \\
\hline
\end{tabular}


Effect of prepared cracker control and with herbs on fat weight (F.wt), body weight gain ratio, adiposity index (Ad.I) and BMI of hypercholesterolemic rats:

The untreated cholesterol group (positive control) feeding on hypercholesterolemic diet for 8 weeks showed significant increase in fats weight (F.wt), body weight gain, Ad.I and body mass index (BMI) when compared to negative control rats in Table 7 . While treated rat groups which feed on unfortified and fortified crackers $C_{W F}, C_{t h}$,
$\mathrm{C}_{\mathrm{ca}}$ and $\mathrm{C}_{\mathrm{hi}}(100 \%$ wheat flour, $10 \%$ thyme, $10 \%$ carrot and $10 \%$ hibiscus powder) given to obese rats for 4 weeks induced significant decrease in fats weight (F.wt), weight gain and AdI at compared with positive control group as shown in Table 7. These results agree with those reported by (Reddy et al. 2005) who reported that natural phenolic compounds added to crackers were widely used to retard lipid oxidation, any ways of adding these compounds into products as ingredients.

Table 7. Effect of prepared crackers control and with some herbs, on fat weight (F.wt), body weight gain ratio, adiposity index (Ad.I) and BMI of control and hypercholesterolemia rats.

\begin{tabular}{|c|c|c|c|c|}
\hline Parameters & $\begin{array}{c}\text { F. wt } \\
\text { g/ day }\end{array}$ & $\begin{array}{c}\text { B.W.G. } \\
\text { g/ day }\end{array}$ & $\begin{array}{c}\text { Ad.I } \\
(\%)\end{array}$ & $\begin{array}{c}\text { BMI } \\
(\mathrm{gm}) /(\mathrm{cm}) 2\end{array}$ \\
\hline Negative Control & $5.48 \pm 0.15 c$ & $45.19 \pm 4.28 b$ & $3.5 \pm 0.10 \mathrm{~d}$ & 0.37 \\
\hline Positive Control & $14.50 \pm 0.22 \mathrm{a}$ & $98.95 \pm 7.89 a$ & $6.93 \pm 0.15 a$ & 0.41 \\
\hline Unfortified crackers & $7.44 \pm 0.13 \mathrm{~b}$ & $41.65 \pm 5.89 c$ & $4.90 \pm 0.12 \mathrm{c}$ & 0.38 \\
\hline Fortified crackers with $10 \%$ Thyme & $7.00 \pm 0.10 \mathrm{c}$ & $43.56 \pm 3.21 b c$ & $4.55 \pm 0.18 \mathrm{c}$ & 0.39 \\
\hline Fortified crackers with $10 \%$ Carrot & $6.71 \pm 0.10 \mathrm{c}$ & $45.01 \pm 4.26 b$ & $4.32 \pm 0.15 c$ & 0.40 \\
\hline Fortified crackers with $10 \%$ Hibiscus & $7.13 \pm 0.13 b$ & $42.56 \pm 4.21 b c$ & $4.67 \pm 0.10 \mathrm{c}$ & 0.38 \\
\hline
\end{tabular}

Values with the same letters indicate non- significant difference $(P<0.05)$ and vice versa.

Effect of prepared cracker control and with herbs on lipids profile and atherogenic-index of hypercholesterolemia rats: As demonstrated in Table 8, rats feeding on hypercholesterolemic diet for 8 weeks produced significant $(\mathrm{P}<0.05)$ increases in serum levels of TC, TG, LDL-c and VLDL-c in positive control when compared with normal control rat group. However there was a significant decrease in TC, TG, LDL-c, VLDL-c and atherogenic index levels of treated rat groups unfortified and fortified crackers with (100\% wheat flour, $10 \%$ thyme, $10 \%$ carrot, and $10 \%$ hibiscus powders) when compared with untreated cholesterol rats (positive control) group $(\mathrm{p}<0.05)$. However there is decrease between the treated groups fortified crackers with $\mathrm{C}_{\mathrm{th}}, \mathrm{C}_{\mathrm{Ca}}$ and $\mathrm{C}_{\mathrm{hi}}(10 \%$ thyme, $10 \%$ carrot, and $10 \%$ hibiscus powder,), the best reduction in cholesterol level, atherogenic index in thyme group. The results were in the line with (Ozkol et al. 2013) who found that the lipid profile was ameliorated especially by supplementations of thymus vulgaris on diabetic rats. This results also agree with (Hopkins et al. 2013) who study the effectiveness of hibiscus in the treatment of hypertension and hyperlipidemia. And (Manach et al., 2004) who found the relationship between the antioxidant compounds in plants and their effectiveness in the treatment of these diseases have been previously described.

Table 8. Effect of prepared crackers control and with some herbs powder on lipids profile and atherogenic index of control and hypercholesterolemia rats.

\begin{tabular}{|c|c|c|c|c|c|c|}
\hline$\overline{\text { Parameters }}$ & $\begin{array}{l}\text { T. Ch } \\
\text { mg/dl }\end{array}$ & $\begin{array}{c}\text { T.G. } \\
\text { mg/dl }\end{array}$ & $\begin{array}{c}\text { HDL-C } \\
\text { mg/dl }\end{array}$ & $\begin{array}{c}\text { LDL-C } \\
\text { mg/dl }\end{array}$ & $\begin{array}{c}\text { VLDL-C } \\
\text { mg/dl }\end{array}$ & $\begin{array}{c}\text { Atherogenic } \\
\text { Index }\end{array}$ \\
\hline Negative Control & $77.30 \pm 3.66 \mathrm{c}$ & $81.84 \pm 3.65 b$ & $41.75 \pm 1.13 \mathrm{a}$ & $19.18 \pm 1.23 \mathrm{c}$ & $16.37 \pm 1.08 \mathrm{~b}$ & $1.85 \pm 0.098 \mathrm{~b}$ \\
\hline Control & $156.69 \pm 4.98 \mathrm{a}$ & $166.58 \pm 3.69 \mathrm{a}$ & $31.48 \pm 1.87 \mathrm{~b}$ & $59.89 \pm 5.67 \mathrm{a}$ & $33.32 \pm 1.82 \mathrm{a}$ & $076 a$ \\
\hline ied crackers & $80.28 \pm 4.45 c$ & $93.46 \pm 2.55 b$ & $39.12 \pm 2.11 \mathrm{a}$ & $22.47 \pm 2.01 \mathrm{c}$ & $18.69 \pm 1.64 b$ & $56 b$ \\
\hline crackers with $10 \%$ Thyme & $75.19 \pm 2.84 \mathrm{c}$ & $89.19 \pm 5.23 b$ & $42.24 \pm 1.09 \mathrm{a}$ & $15.11 \pm 2.17 \mathrm{c}$ & $17.84 \pm 2.09 b$ & $1.78 \pm 0$. \\
\hline Fortified crackers with $10 \%$ Carrot & $77.19 \pm 2.19 \mathrm{c}$ & $82.46 \pm 4.54 b$ & $41.55 \pm 1.54 \mathrm{a}$ & $19.15 \pm 2.44 \mathrm{c}$ & $16.49 \pm 1.33 b$ & $1.8 \pm 0.056 \mathrm{~b}$ \\
\hline Fortified crackers with $10 \%$ Hibiscus & $79.67 \pm 1.99 \mathrm{c}$ & $80.52 \pm 1.96 b$ & $43.61 \pm 2.03 \mathrm{a}$ & $19.96 \pm 3.22 \mathrm{c}$ & $16.10 \pm 1.11 \mathrm{~b}$ & $1.83 \pm 0.054 \mathrm{~b}$ \\
\hline
\end{tabular}

Values with the same letters indicate non- significant difference $(\mathbf{P}<0.05)$ and vice versa.

Effect of prepared cracker control and with herbs on serum kidney function parameters of hypercholesterolemia rats:

On the other hand, the study also showed some kidney function parameters of different treated rat groups (Table 9) the uric acid, urea and creatinine levels of untreated rat group (positive control) were significantly different $(p<0.05)$ from the normal control rat group. However treated rat group $\mathrm{C}_{\mathrm{WF}}$ feeding on unfortified crackers significantly reduced uric acid, urea and creatinine $(\mathrm{p}<0.05)$ compared to positive control, while treated rat groups with fortified crackers $\mathrm{C}_{\mathrm{th}}, \mathrm{C}_{\mathrm{Ca}}$ and $\mathrm{C}_{\mathrm{hi}}$ improved these parameters to a level similar compared to normal control rat group. The highest levels of uric acid, urea nitrogen and creatinine levels in untreated cholesterol group (positive control) were 3.87, 25.48 and 2.75 respectively while rats feeding on crackers with $\mathrm{C}_{\mathrm{WF}}$ $(100 \%$ wheat flour) were 2.01, 18.95 and 1.49 , respectively. Rats feed on crackers fortified with thyme showed the best results in urea and creatinine levels. These results agreed with (Amarowicz et al., 2008) who reported that therapeutic potential of thyme depended on its contents of flavonoids, thymol, eugenol, carvacrol, aliphatic phenols as well as luteolin, tetramethoxylated flavones and saponins.

Effect of prepared cracker control and with herbs on some liver functions of control and hypercholesterolemia rats:

The data in Table (10) showed some liver function parameters, it was observed that the untreated cholesterol rats group (positive control) showed significant increase in ALT, AST and ALP at $p<0.05$ in comparing with normal control group. The treated rats groups $\mathrm{C}_{\mathrm{th}}, \mathrm{C}_{\mathrm{Ca}}$ and $\mathrm{C}_{\mathrm{hi}}$ had the lowest ALT, AST and ALP levels, the best values were $C_{t h}$ group $30.71,52.37$ and 45.10 respectively while $\mathrm{C}_{\mathrm{Ca}}$ group were $32.84,52.11$ and 45.91 respectively followed by $C_{h i}$ which were 34.11, 57.71 and 47.34 respectively. (Monira and Naima 2012) concoulded that treatment with thyme extract in paracetamol intoxicated rats reduced levels of serum transaminases, ALP and total bilirubin towards normal indicating to its hepatoprotective effect and demonstrated membrane stabilizing activity of thyme extract. 
Table 9. Effect of prepared cracker with some herbs on of serum kidney function parameters of control and hypercholesterolemia rats.

\begin{tabular}{|c|c|c|c|}
\hline Parameters & $\begin{array}{c}\text { Uric acid } \\
\mathrm{mg} / \mathrm{dl}\end{array}$ & $\begin{array}{c}\text { Urea } \\
\mu / \mathrm{mg}\end{array}$ & $\begin{array}{c}\text { Creatinine } \\
\text { mg/dl }\end{array}$ \\
\hline Negative Control & $1.73 \pm 0.26 \mathrm{c}$ & $19.75 \pm 1.13 \mathrm{a}$ & $1.27 \pm 0.01 \mathrm{~b}$ \\
\hline Positive Control & $3.87 \pm 1.01 \mathrm{a}$ & $25.48 \pm 1.87 \mathrm{~b}$ & $2.75 \pm 0.11 \mathrm{a}$ \\
\hline Unfortified crackers & $2.01 \pm 0.81 \mathrm{~b}$ & $18.95 \pm 1.54 \mathrm{a}$ & $1.49 \pm 0.02 \mathrm{~b}$ \\
\hline Fortified crackers with $10 \%$ Thyme & $1.91 \pm 0.77 \mathrm{c}$ & $15.62 \pm 2.11 \mathrm{a}$ & $1.68 \pm 0.12 b$ \\
\hline Fortified crackers with10\% Carrot & $1.97 \pm 0.67 \mathrm{~b}$ & $17.21 \pm 2.03 \mathrm{a}$ & $1.75 \pm 0.13 \mathrm{~b}$ \\
\hline Fortified crackers with $10 \%$ Hibiscus & $1.84 \pm 0.74 \mathrm{c}$ & $18.24 \pm 1.09 \mathrm{a}$ & $1.18 \pm 0.18 \mathrm{~b}$ \\
\hline
\end{tabular}

Values with the same letters indicate non- significant difference $(P<0.05)$ and vice versa.

Table 10. Effect of prepared cracker with some herbs on some liver functions of control and hypercholesterolemia rats.

\begin{tabular}{|c|c|c|c|}
\hline Parameters & $\begin{array}{l}\text { ALT } \\
\mu / \mathrm{ml} \\
\end{array}$ & $\begin{array}{c}\text { AST } \\
\mu / \mathrm{ml} \\
\end{array}$ & $\begin{array}{c}\text { ALP } \\
\mu / \mathrm{ml}\end{array}$ \\
\hline Negative Control & $29.35 \pm 1.12 b$ & $51.17 \pm 5.81 \mathrm{c}$ & $44.17 \pm 5.66 \mathrm{~b}$ \\
\hline Positive Control & $46.55 \pm 3.35 \mathrm{a}$ & $79.39 \pm 9.61 \mathrm{a}$ & $60.38 \pm 5.81 \mathrm{a}$ \\
\hline Unfortified crackers & $36.17 \pm 2.01 \mathrm{~b}$ & $55.14 \pm 8.10 \mathrm{c}$ & $49.73 \pm 4.37 \mathrm{~b}$ \\
\hline Fortified crackers with $10 \%$ Thyme & $30.71 \pm 1.81 \mathrm{~b}$ & $52.37 \pm 6.01 \mathrm{c}$ & $45.10 \pm 4.11 \mathrm{~b}$ \\
\hline Fortified crackers with10\% Carrot & $32.84 \pm 0.74 \mathrm{~b}$ & $52.11 \pm 4.13 \mathrm{c}$ & $45.91 \pm 3.11 \mathrm{~b}$ \\
\hline Fortified crackers with $10 \%$ Hibiscus & $34.11 \pm 3.65 \mathrm{~b}$ & $57.71 \pm 6.15 \mathrm{c}$ & $47.34 \pm 5.01 \mathrm{~b}$ \\
\hline
\end{tabular}

Values with the same letters indicate nonsignificant difference $(\mathbf{P}<0.05)$ and vice versa.

AST: Aspartate amino transferase ALT :Alanine amino transferase ALP: Alkaline phosphatase

Effect of prepared cracker control and with herbs on and decreased MDA levels comparing with positive control. Serum Total Antioxidant Capacity (TAC), The treated rat group $\mathrm{C}_{\mathrm{th}}, \mathrm{C}_{\mathrm{Ca}}$ and $\mathrm{C}_{\mathrm{hi}}$ feeding on fortified Malondialdehyde (MDA), Superoxide Dismutase (SOD), cracker had the highest acetylcholine esterase (AChE) levels and Acetylcholine Esterase (AChE) of control and which was similar to the values of normal control group. hypercholesterolemia rats.

The result postulated in Table (11) revealed that levels of TAC and SOD for normal control rats were (3.99 $\pm 0.58 \mathrm{u} / \mathrm{mg}$ and $30.97 \pm 0.54 \mathrm{a} \mu / \mathrm{ml}$ ), while the corresponding levels for positive control group were lower $(1.12 \pm 0.35$ $\mathrm{u} / \mathrm{mg}$ and $20.54 \pm 0.71 \mu / \mathrm{ml})$. Data showed a significant increase in TAC and SOD levels and a significant decrease in MDA in all rat groups which treated with fortified cracker with herbs as compared to the positive control groups. The treated rats groups with $\mathrm{C}_{\mathrm{th}}, \mathrm{C}_{\mathrm{ca}}$ and $\mathrm{C}_{\mathrm{hi}}$ feeding on fortified cracker increased total antioxidant capacity TAC and SOD Fortification with herbs to diet increased antioxidant parameters such as TAC, SOD, and acetylcholine esterase (AChE) levels. These results agreed with (Rasooli et al., 2006) who reported that thyme possess various has beneficial effects, as antimicrobial, antiseptic, antioxidant properties and it has recently suggested as a natural replacement for synthetic antioxidant. (Atawodi, 2005) studied that, hibiscus showed tremendous promise for preventive intervention in the pathogenesis of many diseases, such as cancer and ulcer this rested to the antioxidant compounds in plants

Table 11. Effect of prepared cracker with some herbs on serum total antioxidant capacity (TAC) malondialdehyde (MDA), superoxide dismutase (SOD), and acetylcholine esterase (AChE) of control and hypercholesterolemia rats.

\begin{tabular}{|c|c|c|c|c|}
\hline Parameters & $\begin{array}{c}\text { TAC } \\
\text { (U/mg) }\end{array}$ & $\begin{array}{c}\text { MDA } \\
\mu \mathrm{mol} / \mathrm{mg}\end{array}$ & $\begin{array}{c}\text { SOD } \\
(\mu / \mathrm{ml})\end{array}$ & $\begin{array}{c}\text { Acetylcholine esterase (AChE) } \\
\text { Nmol }\end{array}$ \\
\hline Negative Control & $3.99 \pm 0.58 \mathrm{a}$ & $1.54 \pm 0.54 \mathrm{~d}$ & $30.97 \pm 0.54 a$ & $7.15 \pm 0.4^{\mathrm{a}}$ \\
\hline Positive Control & $1.12 \pm 0.35 \mathrm{~d}$ & $4.79 \pm 0.65 a$ & $20.54 \pm 0.71 d$ & $3.54 \pm-0.4^{\mathrm{c}}$ \\
\hline Unfortified crackers & $2.42 \pm 0.77 \mathrm{c}$ & $2.11 \pm 0.58 \mathrm{bc}$ & $24.52 \pm 0.28 \mathrm{c}$ & $5.96 \pm 0.7^{\mathrm{a}}$ \\
\hline Fortified crackers with $10 \%$ Thyme & $2.99 \pm 0.68 \mathrm{~b}$ & $2.13 \pm 0.35 \mathrm{~d}$ & $26.98 \pm 0.84 \mathrm{ab}$ & $6.15 \pm 0.6^{\mathrm{a}}$ \\
\hline Fortified crackers with $10 \%$ Carrot & $2.34 \pm 0.66 \mathrm{~b}$ & $2.68 \pm 0.32 b$ & $25.85 \pm 0.25 b$ & $5.89 \pm 0.4^{b}$ \\
\hline Fortified crackers with $10 \%$ Hibiscus & $2.17 \pm 0.98 b$ & $2.64 \pm 0.74 \mathrm{~d}$ & $24.87 \pm 0.24 \mathrm{~b}$ & $4.19 \pm 0.4^{b}$ \\
\hline
\end{tabular}

Values with the same letters indicate non- significant difference $(\mathbf{P}<0.05)$ and vice versa.

\section{CONCLUSION}

From The results obtained, it could be underline the beneficial effect of using natural antioxidant for stabilizing in crackers, its phenolic compounds which are one of the most important groups and its effect on hypercholesterolemic rats.

\section{REFERENCES}

A.A.C.C. (2002). Approved laboratory methods, American Association of Cereal Chemists, Minnesota, USA.

Abdel Azim, A.S. (2007). Technochemical and biological studies on some spices and their volatile oils used in bakery products. M.Sc. Thesis Fac. Agric. Food Techno. Dept. Cairo Univ., Egypt.
Abd El Rahim, E. A.; Yossef, H.Y.M. and Soliman, A.E. (2003). Natural additives for healthy crackers. J. of Nutrition., 2: 141-161.

Ali, B. H., A. and Blunden, N. G. (2005). Phytochemical, pharmacological and toxicological aspects of Hibiscus sabdariffa L.: a review. Phytotherapy Research,19(5), 369-375.

Ally, N. M. (2001). Effect of addition B-carotene on quality of macaroni and some bakery products. M.Sc. Thesis, Food Science and Technology Dept., Fac. of Agric. Cairo Unvi., Egypt.

Amarowicz, R.; Zegarska, Z.; Rafałowski, R.; Karamac, M. and Kosin, A. (2008). Antioxidant activity and free radical-scavenging capacity of ethanolic extracts of thyme, oregano, and marjoram. Eur. J. Lipid Sci. Technol., 110: 1-7. 
A.O.A.C. (1995). Association of Official Agricultural Chemists. Official Method of Analysis. $17^{\mathrm{th}}$ Ed. 11.

A.O.A.C. (2007). Official methods of analysis. 17th edition Association of Official Analytical Chemists, Washington DC. USA.

Arscott, S.A. and Tanumihardjo, S. A. (2010). Carrots of many colors provide basic nutrition and bioavailable phytochemicals acting as a functional food. Comp. Rev. Food Sci. Food Safety, 9:223-239.

Asal, M. A. (2004). Studies on yellow corn flour fortification with some dairy products and use it in some cereal products. M.Sc. Thesis, Food Sci., Fac. of Agric., Moshtohor, Zagazig Univ., Egypt.

Atawodi, S.E. (2005). Antioxidant potentials of African medicinal plants. Afr. J. Biotechnol. 4: 128-133.

Bartels, H., Bohemer, M. and Heirli, C. (1972). Colorimetric kinetic method of creatinine. Clin. Chem. Acta., 37: 193.

Buettner, R.1.; Parhofer, K.G.; Woenckhaus, M. and Wrede, C.E. (2006). Defining high-fat-diet rat models: metabolic and molecular effects of different fat types, J. Mol Endocrinol. 36(3):485-501.

Campbell, J.A., (1963): Methodology of protein evaluation, PAG. Nutr. Document R. 101 Add 37, June, Meeting, New York.

Cao, G., Alessio, H. and Cutler, R. (1993). Oxygen radical absorbance capacity assay for antioxidants. Free Radic Biol Med.; 14:303-311.

Christian, K.R.; Nair, M.G. and Jackson, J.C. (2006). Antioxidant and cyclooxygenase inhibitory activity of sorrel (Hibiscus sabdariffa). J. Food Compos. Anal.,19, 778-83.

Dapčević, T., Hadnadev, M., and Pojić, M. (2009). Evaluation of the possibility to replace conventional rheological whaet flour quality control instruments with the New Measurement. Agriculturae Conspectus Scientificus 74:169-174.

Deng, Z.; Zhu, H.; Hu, C.; Liu, R. and Tsao, R. (2012). Highly pigmented vegetables: Anthocyanin compositions and their role in antioxidant activities. Food Research International, 46:250-259.

Domaracky, M., P.; Rehak, S.; Juhas and Koppel, J. (2007). Effects of selected plant essential oils on the growth and development of mouse preimplantation embryos in vivo . Physiol. Res., 56: 97-104.

Dorman, H.G.D. and Deans, S.G. (2000). Antimicrobial Plants: Antibacterial Activity of Plant. Appl. Microbiol., 88: 308-316.

Dreosti, I. E. (1993). Vitamin A, C, E and $c \beta$-arotene as protective factors for some cancers. Asia Pac. J. Clin. Nutr., 2(1):21-25.

Fossati, P., L. Prencipe, and Berti, G. (1980). Use of 3.5 dichloro-z-hydroxybenzenesulfonic acid / 4 aminophenazone chromogenic systems in direct enzymic assay of uric acid in serum and urine. Clin. Chem.; 26:227- 231.

Fossati, P. and Prenape, L. (1982). Serum triglycerides deter-mined colorimeterically with enzyme that produce hydrogen peroxide. Clin. Chem., 28: 2077 2080.

Friedwald, W.T.; Levy, R.I. and Fredriclsor, D.S. (1972). Estimation of the concentration of low density lipoprotein cholesterol in plasma without use of the preparative ultracentrifuge. Clin. Chem., 18: 499502.

Guil, J. L.; Torja, M.E. and Rodriguez, C. (1997). Nutritional and toxic factors in selected wild edibe plants, Plant Food Hum. Nutri. 51; 99-107.
Gurpreet, K.D.; Amarjeet, K. and Preeti, A. (2014). Effect of Spices and Herbs on Farinographic Curve Characteristics and Pasting Properties of Dough, International J. Food Nutrition and Safety, 5(2): 5062.

Golay, A.; Ferrara , J. ; Felber, J. and Schneider, H. (1990). Cholesterol lowering effect skim milk from immunized cows in hypercholesterolemic patients .

Goupy, P.; M. Hugues; P. Boivin and Amiot, J. (1999). Antioxidant composition and activity of barley (Hordeumvulgare) and malt extract and of isolated phenolic compunds. J. Sci. Food Agric., 79: 16251634.

Hestrin, S.,( 1949). The reaction of acetylcholine and other carboxylic acid derivatives with hydroxylamine, and its analytical application. J. Biol Chem. 180(1):24961

Hirunpanich, V.; Utaipat, A.; Morales, N.P. and Sato, H. (2005). Antioxidant effects of aqueous extracts from dried calyx of Hibiscus sabdariffa Linn. (Roselle) in vitro using rat low-density lipoprotein (LDL), Biol. Pharm. Bull, 28(3), 481-484

Hopkins, A. L.; Lamm, M. G.; Funk, J. L. and Ritenbaugh, C. (2013). Hibiscus sabdariffa L. in the treatment of hypertension and hyperlipidemia: A comprehensive review of animal and human studies. Fitoterapia, 85, 84-94.

Kind, P.R and King, E.J. (1954). Estimation of alkaline phosphatase activity by determination of hydrolyzed phenol with aminoantipyrene. J. Clin.Path., 7: 322.

Knapka,J.J. and Judge, F.J. (1974). The effects of various levels of dietary fat and apple supplements on growth of golden hamster. Lab. Aniam. Sci.,24: 318325.

Lin, H. H., Chan, K. C., Sheu, J. Y., Hsuan, S. W., Wang, C. J., and Cheng, J. H. (2012). Hibiscus sabdariffa leaf induces apoptosis of human prostate cancer cells in vitro and in vivo. Food Chemistry, 132(2), 880 891.

Lopes-Virella, M.F. ; Stone, S. ; Ellis, S. and Collwell, J.A. (1977): Cholesterol determination in high-density lipoproteins separated by three different methods. Clin. Chem., 23(5): 882-886.

Manach C, Scalbert A, Morand C, Remesy C. and Jimenez, A. A. (2004). Polyphenols: Food sources and bioavailability. Am. J. Clin. Nutr. 79: 727-747.

Maria, L.; Kamińska, I.; Kramer, M.; Kammerer, D.; Carle, R. and Baranski, R. (2013). The content of phenolic compounds and radical scavenging activity varies with carrot origin and root color. Plant Foods Hum Nutr., 68(2):163-170.

Mohamed, R.; Fernandez, J.; Pineda, M. and Aguilar, M. (2007). Roselle (Hibiscus sabdariffa) seed oil is a rich source of gamma-tocopherol, J. of Food Science. 72(3): 207-11.

Monira A. K. and Naima, Z. M. ( 2012). Evaluation of Protective and Antioxidant Activity of Thyme (Thymus Vulgaris) Extract on Paracetamol-Induced Toxicity in Rats Australian Journal of Basic and Applied Sciences, 6(7): 467-474, 1991-8178.

Nishikimi, M., Rao, N. and Yogi, K. (1972). Colorimetric determination of superoxide dismutase. Biochem. Biophys. Res. Common.; 46: 849-854.

NRC (1995). National Research council Nutrient requirements of laboratory animals, fourth revised edition, PP.29-30 National Academy Press. Washington, DC

Ohkawa, H., Ohishi, N. and Yagi, K. (1979). Assay for lipid peroxides in animal tissues by thiobarbituric acid reaction. Anal Biochem.; 95: 351-358. 
Ozkol, H.; Tuluce, Y.; Dilsiz, N. and Koyuncu, I. (2013). Therapeutic potential of some plant extracts used in Turkish traditional medicine on streptozocin-induced type 1 diabetes mellitus in rats. J. of Membr Biol. 246:47-55.

Patton, C. and Crouch, S. (1977). Determination of serum urea enzymatically. J. of Ana. Chem.; 49 : 464 - 469.

Pichon, L., Huneau, J.F., Fromentin,G.and Tomé D.(2006): A high-protein, high-fat,carbohydrate-free diet reduces energy intake, hepatic lipogenesis, andadiposity in rats. J Nutr;136:1256-60.

Pichon, L., Huneau, J.F., Fromentin,G.and Tomé D.(2006): A high-protein, high-fat,carbohydrate-free diet reduces energy intake, hepatic lipogenesis, andadiposity in rats. J Nutr;136:1256-60.

Pichon, L., Huneau, J.F., Fromentin,G.and Tomé D.(2006): A high-protein, high-fat,carbohydrate-free diet reduces energy intake, hepatic lipogenesis,andadiposity in rats. J Nutr;136:1256-60.

Pichon, L., Huneau, J.F., Fromentin,G.and Tomé D.(2006): A high-protein, high-fat,carbohydrate-free diet reduces energy intake, hepatic lipogenesis,andadiposity in rats. J Nutr;136:1256-60.

Pichon, L., Huneau, J.F., Fromentin,G. and Tomé D.(2006): A high-protein, high-fat,carbohydrate-free diet reduces energy intake, hepatic lipogenesis, and adiposity in rats. J Nutr; $136: 1256-60$.

Pichon, L., Huneau, J.F., Fromentin,G.and Tomé D.(2006): A high-protein, high-fat,carbohydrate-free diet reduces energy intake, hepatic lipogenesis,and adiposity in rats. J Nutr;136:1256-6

Pichon, L., Huneau, J.F., Fromentin,G.and Tomé D.(2006): A high-protein, high-fat,carbohydrate-free diet reduces energy intake, hepatic lipogenesis,and adiposity in rats. J Nutr; $136: 1256-6$

Pichon,L.; Huneau, J.F. and Tome, D. (2006). A High protein, high fat, carbohydrate free diet reduces energy intake, hepatic lipogenesis and adiposity in rats. J. Nutr., 136, 1256-60.

Rasooli, I.; Rezaei, M.B. and A. Allameh,( 2006). Ultra structural studies on antimicrobial efficacy of thyme essential oils on listeria monocytogenes. International J. of Infectious Diseases, 10: 236-241.

Reddy V, Urooj A and A.Kumar,(2005). Evaluation of antioxidant activity of some plant extracts and their application inbiscuits. Food Chem 2005; 90: 317321.

Reitman, S. and Frankel, S. (1957): Determination of serum alanine and aspartate aminotransferases (ALT \& AST). Clin .Path. Am. J.; 28: 57-63.

Richmod,W. (1973): Determination of cholesterol by enzymatic colorimetric method. Clin. Chem., 19: 1350 .
Sasaki, K.; Wada, K.; Tanaka, Y.; Yoshimura, T. and Matuoka, K. ( 2005). Thyme (Thmus Vulgaris L.) Leaves and its constituents increase the activities of xenobiotic-metabolizing enzyme in mouse liver. $\mathrm{J}$. Med. Food, 8: 184-189.

Simon P.W. (1990). Carrots and other horticultural crops as a source of provitamin A carotenes. J. Hort Science, 25:1495-1499.

Snedecor, G.W. and Cochran, W.G. (1967). Statistical Methods; 7th Ed., The Lowa State University Press., Ames, Lowa, U.S.A.

Sompong, R., Siebenhandl- Ehn, S. Linsberger-Martin, G. and Berghofer, E. (2011). Physicochemical and antioxidative properties of red and black rice varieties from Thailand, China and Sri lanka. Food Chemistry 124(1): 132-140.

Sutharut, J. and Sudarat, J. (2012). Total anthocyanin content and antioxidant activity of germinated colored rice. International Food Research Journal 19(1): 215-221.

Sun, T.; Simon, P. W. and Tanumihardjo, S. A. (2009). Antioxidant phytochemicals and antioxidant capacity of biofortified carrots (Daucuscarota L.) of various colors. J. Agric. Food Chem., 57:4142-47.

Unver, E. M. and Domolds, C.E. (1976). Water absorption of flour dough and flour fraction from spring wheat. Bakers digest 50(5): 19. C.F. food Sci. Technol. Abst. 9(6): 605 .

Vincent, A.M.; Russell, J.W.; Low, P. and Feldman, E. L. (2004). Oxidative stres in the pathogenesis of diabetic neuropathy , Endocrine Reviews, 25(4), 612-628.

Wangcharoen, W., Ngarmsak, T. and Wilkinson, B.H. (2005). Snack product consumer surveys: large versus small samples. Food Quality and Preference 16(6): 511-516

Weichselbaum T.F (1946). An accurate and rapid method for the determination of protein in small amount of blood serum and plasma. Am .J. Clin .Path.; (16):40

Yang, M. Y., Peng, C. H., Chan, K. C., Yang, Y. S., Huang, C. N., and Wang, C. J. (2010). The hypolipidemic effect of Hibiscus sabdariffa polyphenols via inhibiting lipogenesis and promoting hepatic lipid clearance. J. of Agric. and Food Chem., 58(2), 850 859.

Zhang, D. and Hamauzu, Y. (2004). Phenolic compounds and their antioxidant properties in different tissues of carrots (Daucuscarota L.) J. Food Agric. Environ., 2:95-100.

Zhen, A. and Jing, N. (2016). Phytochemistry, antioxidant capacity, total phenolic content and antiinflammatory activity of Hibiscus sabdariffa leaves. J. of Food chemistry 190: 673-680.

\footnotetext{
تأثير استخدام الزعتر و الجزر و الكركديه لبعض منتجات المقرمشات على قيمتها الغذائية و العلاجية

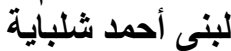
قسم الاقتصاد المنزلى ـ كلية التربية التوعية - جامعة المنصورة - مصر

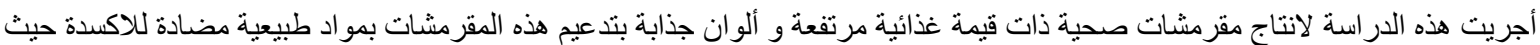

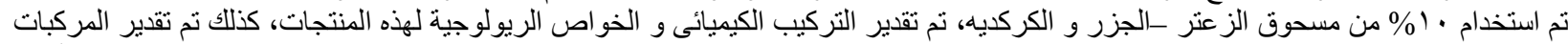

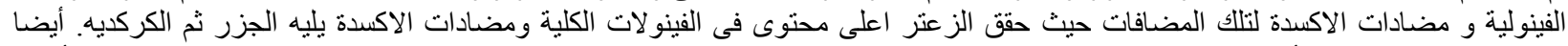

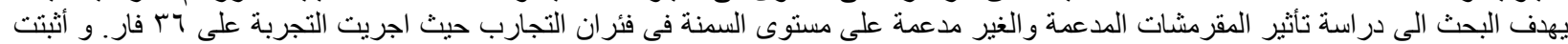

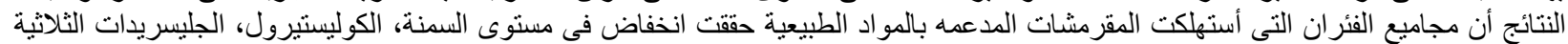

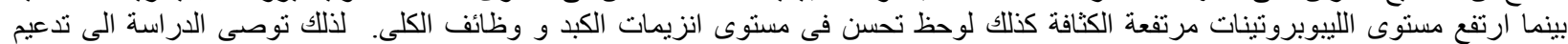
المقرمشات بمضافات طبيعية مثل الزعتر ، الجزر و الكركديه لانتاج مقرمشات بالو ان صحية ولها قيمة غذائية مرتفعة خاصة للاطفال
} 